\title{
Campos de estupro: as mulheres e a guerra na Bósnia*
}

\author{
Andréa Carolina Schvartz Peres**
}

\section{Resumo}

A guerra na Bósnia-Herzegóvina organizou territórios etnicamente e redefiniu as categorias étnico-nacionais - sérvia, croata e bosniac (muçulmana). Enquanto os soldados combatiam nas linhas de frente, inúmeras eram as atrocidades testemunhadas em outros campos de batalha: casas, vilas, cidades, campos de detenção $e$ concentração e os campos de estupro. Faço neste artigo uma revisão da discussão acerca do estupro na guerra na Bósnia, como este pode ser visto como arma de guerra e um instrumento de limpeza étnica e de tentativa de extermínio.

Palavras-chave: Bósnia-Herzegóvina, Estupro, Limpeza Étnica, Nacionalismo, Gênero.

* Recebido para publicação em 02 de julho de 2011, aceito em 22 de setembro de 2011.

** Doutora em Antropologia Social (PPGAS/IFCH/Unicamp). acsperes@gmail.com

cadernos pagu (37), julho-dezembro de 2011:117-162. 
Campos de estupro

Rape Camps: Women and War in Bosnia

\begin{abstract}
The war in Bosnia and Herzegovina ethnically organized territories and redefined the ethno-national categories and groups - Serbs, Croats and Bosnians (Muslims). Beside the battles between soldiers at the front lines, several atrocities used to happen in other fields: homes, villages, cities, detention places, concentration camps, and the rape camps. This article introduces the debate about the rapes that occurred during the war in Bosnia and the ways to understand them: as a war weapon, as an ethnic cleansing tool, as an attempt to extermination.
\end{abstract}

Key Words: $\quad$ Bosnia and Herzegovina, Rape, Ethnic Cleansing, Nationalism, Gender. 
Mote

A guerra na Bósnia-Herzegóvina ${ }^{1}$, datada de 1992 a 1995, organizou territórios etnicamente e redefiniu as categorias étniconacionais - sérvia, croata e bosniac (muçulmana).

Enquanto os soldados combatiam nas linhas de frente, inúmeras eram as atrocidades testemunhadas em outros campos de batalha: casas, vilas, cidades, campos de detenção $e$ concentração e os campos de estupro.

Nos campos de estupro, geralmente escolas, armazéns, ginásios, hotéis, as mulheres - principalmente as bosniaquinhas (muçulmanas bósnias) $^{2}$ - eram obrigadas a ter relações sexuais com mais de um soldado e várias vezes. Algumas ficavam presas durante meses até engravidarem e não poderem mais abortar. Em termos numéricos, calcula-se que cerca de vinte mil mulheres muçulmanas e croatas foram estupradas durante a guerra.

Controle de mentes, controle de corpos, controle da descendência - que é patrilinear, no caso da Bósnia - e do território eram os objetivos daqueles que faziam a guerra.

Todavia, os estupros de mulheres durante a guerra na Bósnia são um tema tabu. Com exceção de Bakira Hasečić, que tornou público seu sofrimento $e$ o transformou em uma bandeira política para todas as mulheres estupradas no conflito, pouco se sabe sobre quem elas são e quem são seus filhos. Ou seja, o lugar oficial da mulher na guerra, mesmo quando vítima, é um lugar fora dela. Daí o silêncio, sua despersonalização, sua despolitização.

O silêncio a respeito da violação dos corpos durante a guerra marcou minha pesquisa de campo. Conversas sobre o

1 Daqui em diante, escreverei, por vezes, somente Bósnia.

2 Exceto os nomes dos países e de suas capitais, que possuem grafia na língua portuguesa, opto por manter a grafia original dos nomes de cidades e pessoas. "Bosniaquinha" é o modo transliterado por mim de Bošnjakinja; "bosniac", "ustasha" e "chetnik" são termos adaptados da grafia inglesa. 
antes e o depois da guerra apareciam facilmente, mas o durante era apresentado como itens em sequência e separados por vírgulas - "foi uma guerra que contou com campos de detenção e de concentração, torturas, assassinatos, massacres, genocídios, estupros..." - ou aparecia em frases como "você sabe, tem nos livros, passou na televisão, não há muito que falar"; um sofrimento sem nome e sem rosto anunciava a perda do ente querido do outro, a mulher (genérica) bosniaquinha estuprada, o genocídio. De fato, Veena Das (1999) já chamara a atenção para a impossibilidade de se relatar o que chama de violência vertical, ou seja, aquela que desafia o que é próprio do humano e da vida, e por isso é indizível.

Neste artigo, esses assuntos serão tratados, inclusive, no silêncio que os determina, como forma de apontar caminhos para futuras pesquisas sobre a Bósnia, e reflexões sobre o estupro em contextos de guerra.

Numa guerra de extermínio, ou de "limpeza étnica", como ocorreu na Bósnia, fazer as mulheres terem os filhos é controlar a descendência, matando seus homens e dominando a prole, e, concordando com Hayden (2000), transformando animosidade em ódio e medo, impelindo o outro a não retornar.

A guerra não atingiu seu objetivo último: a Bósnia permaneceu enquanto Estado, as mulheres não foram renegadas por suas famílias e suas crianças não "viraram sérvias". Entretanto, um dos itens do acordo que colocou fim à guerra é o retorno dos refugiados a suas casas e vilas. O estupro, mais do que qualquer outra "arma", garantiu que isso não ocorra tão cedo, trazendo para o campo da intimidade o sofrimento $e$ impedindo qualquer aproximação ou "reconciliação" possível.

Redefiniram-se, assim, as categorias étnico-nacionais, antes negociadas no dia-a-dia, quando a convivência era a regra, marcando-as na intimidade da mulher, no seu ventre, em seu filho. O medo foi plantado, não se sabe por quanto tempo ainda. 


\section{Introdução}

O que chamo aqui de mote foi o resumo encaminhado para os cadernos pagu. Eu havia então lido muito pouco sobre o assunto, dado que não era esse meu tema de pesquisa quando realizei trabalho de campo em Sarajevo, na Bósnia-Herzegóvina, entre 2007 e $2009^{3}$. Quando o releio agora, percebo que é como se nele descrevesse o que ficou das narrativas que ouvi em campo. Nele transparece a emoção e a indignação que o assunto suscita $e$, também, a fala dos que sofreram a agressão (termo que discuto logo adiante).

Resolvi transformá-lo em mote, para explicitar de onde parto e os tópicos, e equívocos, nele contidos. Antes, algumas informações básicas sobre como se organizavam as nacionalidades na ex-lugoslávia e sobre o que foi a guerra na Bósnia, antiga república deste país.

Notas sobre nação e nacionalidade na ex-Iugoslávia

A República Federativa Socialista da Iugoslávia reconhecia duas categorias principais relativas à identidade nacional $e$ referentes a direitos nacionais: as nações $e$ as nacionalidades. A primeira categoria, "nações da lugoslávia" (narodi ou nacije), englobava os sérvios, os croatas, os eslovenos, os macedônios, os montenegrinos e os muçulmanos. Cada uma delas possuía direitos constitucionais de igual representação política e um lar nacional em uma das repúblicas, exceto a Bósnia-Herzegóvina "Iugoslávia em miniatura" - que era constituída por três nações (sérvia, croata e muçulmana). As "nacionalidades da Iugoslávia" (narodnosti) - em outras paragens, as chamadas "minorias" -

${ }^{3}$ Realizei estágio sanduíche de 14 meses em Sarajevo, na IUS (International University of Sarajevo), com recursos da Capes, sendo meu doutorado na Unicamp financiado pela Fapesp.

${ }^{4}$ Assim a chamavam, muitas vezes, para explicar a especificidade da Bósnia na ex-Iugoslávia. 
tinham garantida a diversidade de direitos culturais e linguísticos e não tinham ou não habitavam seu "lar nacional". Os "iugoslavos" $e$ "outros" eram englobados nessa segunda categoria.

No caso da Bósnia, a definição nacional de "sérvios", "croatas" e "muçulmanos" é posterior à existência dos grupos em si. Tal definição tem raiz religiosa, mesmo quando a pessoa é ateia, ou não é religiosa; os sérvios representariam os cristãos ortodoxos; os croatas, os católicos; e os muçulmanos, aqueles adeptos do islamismo. A partir de 1993, o termo oficial para designar os muçulmanos passou a ser "bosniac" (Bošnjak), embora muitos ainda se refiram a estes como "muçulmanos". Cabe sublinhar novamente que "muçulmano" entra aqui como "nação" - uma das três nações constitutivas da Bósnia - e não necessariamente como religião.

No caso da Bósnia não houve uma tentativa de se impor uma identidade nacional bósnia ou herzegóvina ${ }^{5}$ (exceto uma mal-sucedida, durante o império austro-húngaro) - o mesmo podemos dizer em relação à identidade "iugoslavo". Hoje, uma identidade nacional bósnia - ou melhor, pessoas que se definem como bósnios primeiramente - aparece como forma, ou mesmo como manifesto contra as divisões nacionais impostas pela guerra.

Independente das definições existentes e da discussão em antropologia sobre o que é etnia, nacionalidade e religião - não que as definições nativas não estejam também informadas por estas - na Bósnia cabem todas elas, mas seu uso varia conforme o que se queira enfatizar. "Etnia", entretanto, acaba por ser um termo explicativo/descritivo. Ninguém diz "minha etnia é bosniac", mas eu sou bosniac, minha nacionalidade é bosniac, minha religião é muçulmana. As descrições do conflito utilizam, no

\footnotetext{
5 A Herzegóvina é a região sul da Bósnia-Herzegóvina, sem conotação nacional, apesar de possuir regiões historicamente mais homogêneas de maioria croata $e$ outras de maioria sérvia nas partes fronteiriças com a Croácia e a Sérvia, respectivamente.
} 
entanto, termos como diferenças étnicas, pertença étnica, limpeza étnica, conflito étnico.

Talvez ainda pareça confuso para uma pessoa não familiarizada com o contexto bósnio o que são precisamente tais distinções nacionais e de que modo elas estão presentes ou não nas narrativas locais. Concordando com Bringa, ser muçulmano na Bósnia é (ou era?) uma identidade ligada a uma religião, mas também a um modo de práticas, a uma moral e costumes definidos na casa e em relação aos grupos vizinhos, que compartilhavam relações de vizinhança e de ajuda mútua, definindo os muçulmanos da Bósnia enquanto grupo e enquanto grupo que se diferencia dos católicos/croatas e dos ortodoxos/sérvios. Porém, o que antes era uma identidade construída "em relação a", com a guerra, vira um demarcador de diferença, "em oposição a" (Bringa, 1995:231).

Antes da guerra, a identidade nacional não era, portanto, algo que determinava a pessoa por completo, aparecendo oficialmente, de tempos em tempos, nos censos populacionais, nos feriados religiosos, na nominação dos filhos e em um modo de práticas e costumes dentro da casa e "em relação a". Nas palavras de Bougarel, Helms e Duijzings (2007:16),

as identificações étnico-nacionais na Bósnia eram fluidas $e$ contextuais, (...) as relações inter-étnicas eram baseadas em regras estáveis de reciprocidade que, não obstante, eram negociadas no dia-a-dia, e (...) a coexistência pacífica não implicava o ofuscamento das fronteiras étnicas. ${ }^{6}$

\footnotetext{
6 Todas as citações neste artigo foram traduzidas por mim do inglês e do bósnio. Nas notas de rodapé, trago a citação original: "ethno-national identifications in Bosnia were fluid and contextual, (...) interethnic relations were based on stable rules of reciprocity that were nonetheless negotiated on a day-to-day basis, and (...) peaceful coexistence did not amount to a blurring of ethnic boundaries".
} 
Casamentos mistos eram frequentes especialmente nas cidades, onde fui informada que "quem é quem" nunca foi uma questão, como passou a ser com a guerra e desde então.

A guerra colocou, portanto, a questão nacional em primeiro plano. E após matar os homens, apropriou-se do corpo das mulheres, dominando todos os espaços como se não houvesse mais a necessidade ou possibilidade de uma convivência futura, como espero demonstrar neste artigo.

A guerra

\author{
o nacionalismo extremo na ex- \\ Iugoslávia não consistiu apenas em \\ imaginar supostas comunidades \\ "primordiais", mas sobretudo, em \\ tornar inimagináveis as comunidades \\ heterogêneas existentes. \\ (Hayden, 1996a:783) ${ }^{7}$
}

A guerra na Bósnia-Herzegóvina é um marcador fundamental dos processos identitários que se desenrolaram naquele território, dado que foi uma guerra cujas categorias nacionais - "muçulmanos"8, "sérvios" e "croatas" - definiram os lados do conflito e tendo em vista que foi uma guerra caracterizada pela violência hedionda e pela limpeza étnica, via expulsão, agressão, assassinatos, tortura, estupros, massacres $e$ medo, que levou à reorganização populacional $e$ à divisão do território.

\footnotetext{
7 “(...) extreme nationalism in the former Yugoslavia has not been only a matter of imagining allegedly "primordial" communities, but rather of making existing heterogeneous ones unimaginable."

8 Como afirmei, o termo "bosniac" para designar os "muçulmanos" data de 1993. Há uma dificuldade e, podemos dizer, trata-se de um anacronismo utilizálo em momentos anteriores. Para facilitar a leitura, mantenho os dois termos em outras partes do texto.
} 
O Acordo de Dayton, que pôs fim ao confronto armado no final de 1995, legitimou a divisão pela guerra do território bósnio, reconhecendo duas entidades, uma de maioria sérvia, a Republika Srpska (RS, ou República Sérvia, com 49\% do território), outra de maioria muçulmano-croata, a Federação da Bósnia-Herzegóvina (ou somente Federação, como as pessoas de modo geral a chamam, com $51 \%$ do território) ${ }^{9}$; além do distrito de Brčko, onde ainda se espera uma resolução que defina a qual entidade irá pertencer.

O Acordo estabelece ainda que o poder seja dividido entre as três nacionalidades constitutivas, a sérvia, a croata $e$ a bosniac (demais grupos nacionais entram na categoria "outros"), direitos sociais e políticos dependem assim da adscrição do sujeito a esses grupos, e ser "outro" (ou ser "bósnio") imputa a sua quaseinvisibilidade na vida política.

Atualmente, o território bósnio é um território homogêneo, ou quase homogêneo, do ponto de vista das entidades, como também das cidades e vilas demarcadas pelas fronteiras invisíveis que dividem grande parte da Federação entre croatas e bosniacs.

A limpeza étnica, fundamental para a homogeneização populacional do território, realizou-se através da transferência de população (literalmente, um ônibus pegava as pessoas em casa $e$ as levava até o território sob domínio dos seus), expulsão e extermínio. Queimas de casas, templos religiosos e plantações, estupros, torturas e assassinatos contribuíram nesse processo, que, podemos dizer, foi bem-sucedido - ao dividir o território, separando pessoas com base em sua ascendência étnico-nacionalreligiosa e fazendo com que o antigo modo de vida, baseado na coexistência e na heterogeneidade, passasse a ser inconcebível. ${ }^{10}$

As noções de "guerra civil" e "agressão" aparecem como as definidoras do conflito. Tais noções definem as verdades

9 A Federação é formada por dez cantões, alguns com maioria bosniac, outros com maioria croata.

${ }^{10}$ Sobre isso, ver também Hayden (1996a, 1996b, 2000). 
contadas, as políticas de identidade, as posições em relação ao conflito e os modos de compreender o que deve ser um estado legítimo e justo. Na Federação, o termo "agressão" é o termo preferido para definir a guerra, na Republika Srpska, o termo "guerra civil". O objetivo da "agressão" era a criação da "Grande Sérvia" (ou da "Grande Croácia"), o objetivo da "guerra civil" era a manutenção da Iugoslávia, ou sua destruição. A guerra dividiu, assim, também as histórias e a compreensão sobre elas.

Pode-se dizer, portanto, que foram várias as guerras, e não só uma a guerra na Bósnia. Além dos lados da guerra, definidos pelas categorias nacionais, diversos foram os campos e modos de combate, os alinhamentos e posicionamentos entre as partes (que se rearranjavam de acordo com lealdades locais/regionais) e as histórias sobre a guerra.

De modo geral, no norte da Bósnia, os territórios estavam sob domínio das forças sérvias e a guerra se dava entre sérvios e não-sérvios (croatas e bosniacs): na região de Posavina (fronteira com a Croácia e a Sérvia) e nas regiões de Banja Luka e Prijedor. ${ }^{11} \mathrm{O}$ leste da Herzegóvina (a parte sul da Bósnia) e o leste da Bósnia como um todo também estavam sob domínio das forças sérvias - cidades como Trebinje, Zvornik, Višegrad, Foča, Bijeljina e muitas outras podem ser citadas. Ambas foram regiões "limpas etnicamente", de onde principalmente muçulmanos/bosniacs foram varridos.

Na Bósnia Central e Mostar, o conflito mais feroz foi entre forças croatas (HVO) e muçulmanas/bosniacs (ABiH), entre 1993 e 1994. Em 1991, houve conflitos entre sérvios e croatas também na Herzegóvina, e a vila croata de Ravno, em Trebinje, foi destruída em outubro daquele ano, aparecendo como umas das primeiras cidades bósnias atacadas pelas forças sérvias.

No nordeste da Bósnia, a guerra se deu principalmente entre forças muçulmanas/bosniacs, já que em 1993, Fikret Abdić, eleito juntamente com Alija Izetbegović nas eleições de novembro

${ }^{11}$ Ver mapa adiante. 
de 1990 para a presidência bósnia, rompeu com este último e auto-proclamou Cazinska krajina (na região de Bihać/Velika Kladuša) território autônomo sob sua liderança.

Em Sarajevo, a guerra se deu sob a forma de cerco. A população viveu por quase quatro anos em condições precárias, bombardeada constantemente e sob a mira de franco-atiradores posicionados nas montanhas que circundam a cidade. Foi uma agressão à cidade, as pessoas explicam, realizada pelas forças sérvias ou pelos chetniks, como eram geralmente chamados. ${ }^{12}$

Mais de uma vez ouvi das pessoas com quem conversei na Federação que "a Republika Srpska só existe porque houve limpeza étnica".

Além das cidades esvaziadas, existiram os chamados "campos de concentração". ${ }^{13}$ Segundo o jornalista Ed Vulliamy, "cada cidadezinha, vila ou aldeia, sob controle sérvio, possuía suas próprias prisões e campos" (1994:115). ${ }^{14}$ Nesses campos, segundo depoimentos ouvidos por Vulliamy, os prisioneiros eram mal alimentados (quando não ficavam dias sem comida ou água), torturados, espancados muitas vezes até a morte e humilhados das mais diversas formas, desde terem de cantar canções épicas ou patrióticas sérvias, como serem forçados a terem relações sexuais uns com os outros. Em alguns deles, também havia mulheres, que eram estupradas cotidianamente. Meldijana, pesquisadora ${ }^{15}$,

12 "Chetnik" (četnik) designava a milícia de maioria sérvia e monarquista, sob liderança de Draža Mihailović, que lutara na Segunda Guerra Mundial. Esse termo foi utilizado novamente nas guerras dos anos 1990, como nome de uma milícia sérvia que então guerreava (os Četnici (pl.) de Vojislav Šešelj), como autodenominação dos combatentes sérvios, e muitas vezes para distinguir "nossos sérvios" daqueles que "nos bombardeavam": os chetniks.

${ }^{13}$ Podemos citar os campos de Manjača, Trnopolje, Keraterm e Omarska, próximos a Prijedor; Kotor Varoš, próximo a Banja Luka; Kula, Kasindolska, Ilidža, Vojničko Polje e Sonja, em Sarajevo e arredores; entre outros.

14 "(...) every small town, village or hamlet under Serbian control had its own prisons and camps".

${ }^{15}$ Conversa com a autora durante o trabalho de campo. 
explica, contudo, que não foram somente mulheres estupradas na guerra, mas também homens e crianças.

Samira, jornalista ${ }^{16}$, comparou o campo de concentração de Omarska com "os de Hitler", pois foi planejado para limpar e matar psicologicamente as pessoas: "[Radovan] Karadžić17 era psicólogo e sabia muito bem o que estava fazendo". Segundo seu relato, os primeiros a serem enviados para os campos foram intelectuais, professores, médicos e empresários; além desses, havia os campos de estupro para as mulheres, que chegavam a ficar três anos presas para terem os bebês.

A violação de mulheres e meninas acontecia ou durante os
expurgos da limpeza étnica, nas casas, nos barracões, em
espaços públicos, ou em "campos" especiais. Algumas
vítimas relataram que eram requisitadas para "servir aos
combatentes sérvios". Na associação para as vítimas do
genocídio em Zenica, há evidência de dezessete "campos
de estupro", principalmente em motéis, escolas, serrarias e
casas privadas. Há mulheres que foram pegas em suas
casas e levadas às linhas de frente, onde eram submetidas
"aos mais bestiais dos abusos". Em Foča, mulheres relatam
estupros em público, na frente de maridos e crianças, de
vizinhos e de outros soldados (Vulliamy, 1994:199). ${ }^{18}$

${ }^{16}$ Idem.

${ }^{17}$ Karadžić foi líder dos sérvios bósnios e presidente da Republika Srpska, autoproclamada no começo de 1992. Em 2008, foi finalmente preso por genocídio e crimes de guerra e levado para julgamento em Haia, pelo TPI (Tribunal Penal Internacional para a ex-Iugoslávia).

18 "The violation of women and girls took place either during the ethnic cleansing purges, in homes, barracks or public places, or else at the special 'camps'. Some victims reported that they were told to 'go and deliver fighting Serbs'. The centre at Zenica [Genocide Centre in Zenica] has accumulated evidence of seventeen 'rape camps', mainly in motels, schools, saw mills or private houses. Other women were taken from their homes to the fighting lines and subjected to 'the most bestial of abuses'. In Foča, women tell of rape in public, in front of husbands and children, neighbours and other soldiers." 
Frei Marko ${ }^{19}$ acredita, entretanto, que as atrocidades ocorreram de todos os lados da guerra. Sérvios cometeram atrocidades em Bosanski Šamac (norte da Bósnia) contra croatas e muçulmanos. Em Vitez, croatas mataram mulheres e crianças. $\mathrm{E}$ mujahidins ${ }^{20}$ fizeram coisas terríveis em Travnik contra sérvios, croatas e judeus.

Para muitas pessoas com quem conversei, os mujahidins foram responsáveis pelas atrocidades do lado muçulmano, como matar civis e prisioneiros de guerra e queimar vilas. Por toda a parte, há um esforço generalizado em culpabilizar "outros" pelas atrocidades. Expressões como "não foram os nossos sérvios, mas chetniks, camponeses, nacionalistas etc. que as cometeram", ou "foram os mujahidins", ou os "ustashas" 21 , traduzem um modo comum de contar a guerra e, ao mesmo tempo, de se distanciar dela.

Não obstante, de acordo com o relatório apresentado no final de 1994 para o Conselho de Segurança da ONU sobre os casos de estupro e violação sexual na guerra, coordenado por Bassiouni (1994), o maior número de pessoas que foram levadas aos campos ou estupradas é de muçulmanos/bosniacs, e os principais perpetradores, sérvios.

Após a invasão das vilas ou cidades, as mulheres muçulmanas/bosniaquinhas eram levadas para os campos, geralmente com idosos e crianças. Seus homens (pais, filhos, irmãos, maridos, primos) ou estavam no exército bósnio, ou haviam fugido, ou foram levados também como prisioneiros, ou já haviam sido mortos.

\footnotetext{
${ }^{19}$ Conversa com a autora durante o trabalho de campo.

${ }^{20}$ Homens que vinham principalmente do Afeganistão, Turquia e Síria (Cf. Vulliamy, 1994) para lutar em nome de Allah e ajudar o povo muçulmano que sofria na guerra.

${ }^{21}$ Os nacionalistas "sanguinários" croatas eram assim chamados (ustaša), remetendo ao termo utilizado por aqueles que se aliaram aos nazistas durante a Segunda Guerra Mundial.
} 
Nos campos, as mulheres eram estupradas diariamente $e$ algumas deliberadamente engravidadas (Cf. Stiglmayer, 1994). Qualquer lugar poderia ser potencialmente um campo - cafés, porões, casas, depósitos -; eram inacessíveis, portanto, difíceis de rastrear e facilmente transferíveis para outros lugares (id.ib.). Passado algum tempo, essas mulheres eram libertadas, mortas, "desaparecidas" ou trocadas por prisioneiros.

Stiglmayer (1994) conta o caso do campo em Doboj (cidade no norte da Bósnia), na escola Đure Pučar, onde duas mil mulheres muçulmanas e croatas e algumas crianças foram aprisionadas. Em seus relatos, as mulheres contam que ficavam no enorme ginásio esportivo da escola, totalmente no escuro, e os homens chegavam com lanternas, escolhiam algumas e levavamnas para as salas de aula - onde as carteiras tinham sido empurradas contra a parede e, no centro, colocados alguns colchões - para serem estupradas. No ginásio, davam-lhes pedaços de pão para comer e a água ficava em baldes; nos baldes vazios, sempre furados, faziam suas necessidades. Muitas relatam que quando lhes estupravam, diziam que era para terem bebês sérvios, ou chetniks.

Segundo Kadira, que esteve aprisionada no campo de Doboj, as mulheres que engravidavam eram separadas das demais, recebiam a visita de ginecologistas, eram protegidas, alimentadas e melhor tratadas. Ela não sabe o que aconteceu com algumas que conheceu quando estava lá, mas acredita que foram levadas para a Sérvia ${ }^{22}$ (Cf. Stiglmayer, 1994:119).

Stiglmayer, que escreveu o livro Mass rape com a guerra ainda em curso, conta que o ginásio de esportes dessa escola em Doboj, posteriormente, passou a servir de abrigo para refugiados sérvios e que não houve mais relatos de estupros ou campos.

\footnotetext{
22 Vários rumores apontam que meninas e mulheres grávidas foram levadas para a Sérvia e Montenegro e nunca mais vistas. Stiglmayer (1994) diz que essas histórias revelam muitas vezes o desejo de que ainda estejam vivas.
} 
Restavam então 1500 muçulmanos na cidade, dos 41 mil que havia em $1991{ }^{23}$

Sonja era um campo de estupro (ou um "bordel") que ficava em um hotel em Vogošća, cidade próxima a Sarajevo. Meldijana $^{24}$ contou-me que o comandante da Unprofor (United Nations Protection Force for Former Yugoslavia), General Lewis MacKenzie, sabia desse campo e dos estupros. Há boatos de que tenha participado de alguns deles. Perguntei sobre isso a um amigo jornalista, que retrucou: "duvido que tenha sido tão idiota. Aqui [em Sarajevo] havia garotas o quanto quisesse, com menos de 16 anos, e que por um maço de cigarros, fariam isso de boa vontade". Sua resposta não é, todavia, menos violenta, mas, como veremos, há uma hierarquização da violência sexual em contextos de guerra, que, podemos dizer, vai do sexo por um maço de cigarros ao estupro em série e por vários homens, ou a atrocidades como ter um objeto cortante enfiado em sua vagina, ou seus testículos amarrados a um motor de moto e assim arrancados de seu corpo (Cf. Bassiouni, 1994).

Em Višegrad, na Bósnia Oriental, depois de assassinadas, as pessoas eram atiradas de pontes sobre o rio Drina. Calcula-se que em torno de 200 mulheres foram estupradas diariamente no hotel Vilina Vlas e depois mortas. Segundo Arnaut (s.d.:13), supõe-se que 400 pessoas foram vítimas de estupro nessa cidade. Em um dos relatos do livro de Stiglmayer (1994), Hasiba, após ser aprisionada em uma estação do corpo de bombeiros, foi estuprada em uma delegacia de polícia e depois em público na ponte nova sobre o rio Drina, diante de "chetniks" e de "muçulmanos" que esperavam a morte. Ela disse que não se

${ }^{23}$ De acordo com o censo de 1991, a cidade e as vilas ao redor tinham população majoritária e equivalente de muçulmanos e sérvios, grande número de croatas e uma minoria de iugoslavos e outros. Para maiores detalhes numéricos ver: Nacionalni..., 1993.

${ }^{24}$ Op. cit.. 
importava mais em ser estuprada, queria apenas sobreviver, assim, fazia o que lhe pediam.

Arnaut (s.d.:13) conta a história de Bakira Hasečić, de Višegrad, hoje presidenta da associação "Mulheres - vítimas da guerra". Primeiramente, seu vizinho "de nacionalidade sérvia" matou seu filho, depois a estuprou no quintal de sua casa. Isso foi em abril de 1992. Em seguida, Bakira foi levada ao porão da delegacia de polícia, onde foi estuprada por Sredoje e Milan Lukić (que trabalhavam na polícia local desde antes da guerra), que conhecia pessoalmente. No mesmo porão, ambos cometiam outros tipos de tortura, como apagar cigarros sobre o corpo das mulheres que aprisionavam e cortá-las com facas, arrancando pedacinhos de pele. Segundo Arnaut, muitas não aguentaram tamanha tortura e acabaram cometendo suicídio.

Várias mulheres de Višegrad reportam a participação de Milan Lukić, líder da unidade paramilitar sérvia "Águias Brancas" (Beli orlovi), e seu primo, Sredoje Lukić, nos estupros (Cf. Arnaut, s.d.). ${ }^{25}$ Os dois foram julgados e condenados em 2009 pelo TPI (Tribunal Penal Internacional para a ex-Iugoslávia) por crimes de guerra e contra a humanidade, mas se livraram das acusações do crime de estupro por falta de evidências. ${ }^{26}$ Chamo a atenção para esse fato, pois ainda é um enigma o que consideram "evidências" num caso de estupro, especialmente os ocorridos em tempos de guerra.

Em Foča, também na Bósnia Oriental, no estádio de esportes "Partizan", mulheres, crianças e idosos foram aprisionados. As mulheres eram levadas à noite para casas $e$ apartamentos onde eram estupradas. Muitos contam a história de Almira, de 12 anos, aprisionada na casa Karamanova, na vila de

\footnotetext{
${ }^{25}$ Em seu livro, Stiglmayer escreve somente Milan L., talvez para não cometer perjúrio, já que seu livro data de 1994, quando ainda não tinha sido indiciado.

${ }^{26}$ Milan cumprirá, a princípio, prisão perpétua, e Sredoje, 30 anos de prisão; o caso encontra-se em fase de apelação. Para mais informações sobre estes $e$ outros casos, ver: http://www.icty.org/action/cases/4.
} 
Miljevina, em Foča, que serviu como campo de estupro. Lá, além dos serviços domésticos, as meninas e mulheres eram submetidas a torturas e estupradas. A última notícia que se teve de Almira é que foi vendida por Radomir Kovač (condenado pelo TPI por estupro e escravidão a 20 anos de prisão) e levada para Montenegro, para servir de escrava sexual.

Algumas mulheres eram aprisionadas com o propósito de engravidar e só libertadas quando não pudessem mais realizar o aborto. A maioria que escapou pôde fazê-lo com segurança em algum hospital. As crianças filhas de estupros eram, geralmente, rejeitadas. Algumas mulheres contam que davam socos na barriga, ou que injetavam água quente pela vagina para tentar expelir o feto (Stiglmayer, 1994). A maioria das crianças nascidas foi entregue para a adoção.

Embora cada um dos lados negue as atrocidades, ou as definam como casos individuais, há indícios de que esses atos foram estrategicamente planejados. Não eram quaisquer cidades as assoladas por estupros, massacres e queimas de casas: apenas aquelas que atrapalhavam o estabelecimento de uma área sérvia, ou bosniac, ou croata homogênea. ${ }^{27}$

Apesar de não haver provas de que os estupros faziam parte de um plano, segundo o relatório para o Conselho de Segurança da ONU (Bassiouni, 1994) ${ }^{28}$,

Alguns casos de estupro ou violência sexual reportados
eram claramente resultados de conduta individual ou de um
grupo pequeno, sem evidência de direção de comando ou
de uma política nesse sentido. No entanto, a maioria dos
casos parece respeitar um padrão. Esses padrões sugerem

${ }^{27} \mathrm{O}$ exemplo mais evidente é Srebrenica. Esta cidade era um enclave muçulmano na Bósnia Oriental, sob domínio das forças sérvias, que a invadiram, mandaram embora as mulheres, capturaram os homens e mataram todos. Valas comuns foram cavadas na mata com antecedência para receber os corpos dos mais de oito mil homens que seriam massacrados logo em seguida.

${ }^{28}$ Não há divisão por páginas nesse relatório disponível na internet. 
fortemente que houve uma política sistemática de estupro e violação sexual, porém, não há provas disso. É evidente que algum nível de organização e de ação grupal é preciso para levar a cabo muitos dos estupros e violações sexuais referidos. Um fator, em particular, que leva a essa conclusão é o grande número dos alegados estupros $e$ violações sexuais ocorridos em locais de detenção. Dos 1100 casos reportados, em torno de 600 ocorreram em locais de detenção. Esses casos não parecem ter ocorrido aleatoriamente e indicam uma política de, ao menos, tolerância em relação ao estupro $e$ à violência sexual, ou fracasso deliberado dos comandantes dos campos e das autoridades locais em exercer comando e controlar seu pessoal. Outros fatores a considerar no que diz respeito a um possível padrão incluem: similaridades das práticas em áreas geográfica não-contíguas; ocorrência simultânea de outras violações do direito humanitário; atividade militar simultânea; atividade simultânea de deslocamento de população civil; elementos comuns dos atos de estupro $e$ violação sexual, com a maximização da vergonha $e$ humilhação não somente da vítima, como também de sua comunidade; e o momento que ocorreu os estupros $e$ violações sexuais reportados. ${ }^{29}$

29 "Some of the reported rape and sexual assault cases are clearly the result of individual or small group conduct without evidence of command direction or an overall policy. However, many more cases seem to be part of an overall pattern. These patterns strongly suggest that a systematic rape and sexual assault policy exists, but this remains to be proved. It is clear that some level of organization and group activity is required to carry out many of the alleged rapes and sexual assaults. One factor, in particular, that leads to this conclusion is the large number of allegations of rape and sexual assault which occur in places of detention. Out of about 1,100 reported cases, about 600 occurred in places of detention. These custodial cases do not appear to be random and indicate a policy of at least tolerating rape and sexual assault or the deliberate failure of camp commanders and local authorities to exercise command and control over the personnel under their authority. Other factors to consider in discerning a possible pattern include: similarities among practices in noncontiguous geographic areas; simultaneous commission of other humanitarian law violations; simultaneous military activity; simultaneous activity to displace civilian populations; common elements of the 
Hayden (2000) desconfia do caráter planejado da violência sexual, mas não nega seu caráter estratégico. Ao analisar a presença $e$ a ausência de estupro em situações de violência em massa, o autor conclui que o estupro acompanha momentos de partilha do território - como a Partição da Índia em 1947, descrita por Veena Das (1995), e como a guerra na Bósnia. O estupro, segundo esse autor, ao produzir o ódio e, acredito, também o medo, assegura a impossibilidade de qualquer coexistência no futuro e garante a efetividade da expulsão. Em suas palavras (2000:33):

\begin{abstract}
A partição (...) não é apenas um estado limiar mas um tempo quando o Estado ele mesmo é limiar, e questões como de quem é o estado e como a população será definida permanecem abertas. Aqui nós temos as circunstâncias nas quais as mensagens acerca da coexistência subordinada ou expulsão serão enviadas. Depois que estas questóes são resolvidas, estupros em massa são improváveis, porque ou a coexistência será reconstituída ou os novos grupos já consolidados estarão separados. ${ }^{30}$
\end{abstract}

Para corroborar sua tese, Hayden (2000:33) aponta que na Índia, em 1947, alguns muçulmanos de Punjab ocidental fugiram para Delhi (para o oriente), e não para o Paquistão (para o ocidente) (...), sentindo (corretamente) que

commission of rape and sexual assault, maximizing shame and humiliation to not only the victim, but also the victim's community; and the timing of the alleged rapes and sexual assaults".

30 "Partition (...) is not only a liminal state but a time when the state itself is liminal, and the questions of whose state it is, and how the population will be defined, are open. Here we have the circumstances in which the messages of subordinated coexistence or expulsion will be sent. After these issues are settled, mass rape is no longer likely, because either coexistence will have been reconstituted or the newly consolidated groups will have separated." 
poderiam continuar vivendo com hindus, mesmo não podendo permanecer em Punjab. ${ }^{31}$

$\mathrm{O}$ mesmo se verifica entre muçulmanos da região predominantemente muçulmana de Sandžak, na Sérvia. Ou seja, tanto em Delhi como em Sandžak não estava em questão o controle do território por um grupo. Concordando com Hayden, os estupros ocorreram em territórios em disputa na Bósnia; quando o controle estava consolidado, não houve mais casos de violência sexual contra as minorias que permaneceram (como observamos em relação a Doboj).

A análise de Hayden é interessante, pois aponta que por mais que a violência sexual seja também uma violência étnica, não há substantivamente nada que indique que esteja na etnia o apetite pela violência, particularmente a sexual; ou seja, não há nada de étnico no estupro, por mais que ele acione tais categorias $e$ as marque nos corpos das mulheres - corpos femininos violados são construídos enquanto territórios étnicos eles mesmos (Žarkov apud Hayden, 2000:32). Por isso, os estupros se deram com maior frequência quando esses territórios ainda não estavam homogeneizados.

\section{$* * *$}

Após termos uma ideia do que foi a guerra $e$ as histórias $e$ suspeitas que a rodeiam, passo agora para as análises sobre o estupro.

31 “(...) in India in 1947, some Muslims from western Punjab fled east to Delhi rather than west to Pakistan (...), feeling (largely correctly) that they could indeed continue to live with Hindus even though they could not stay in Punjab." 


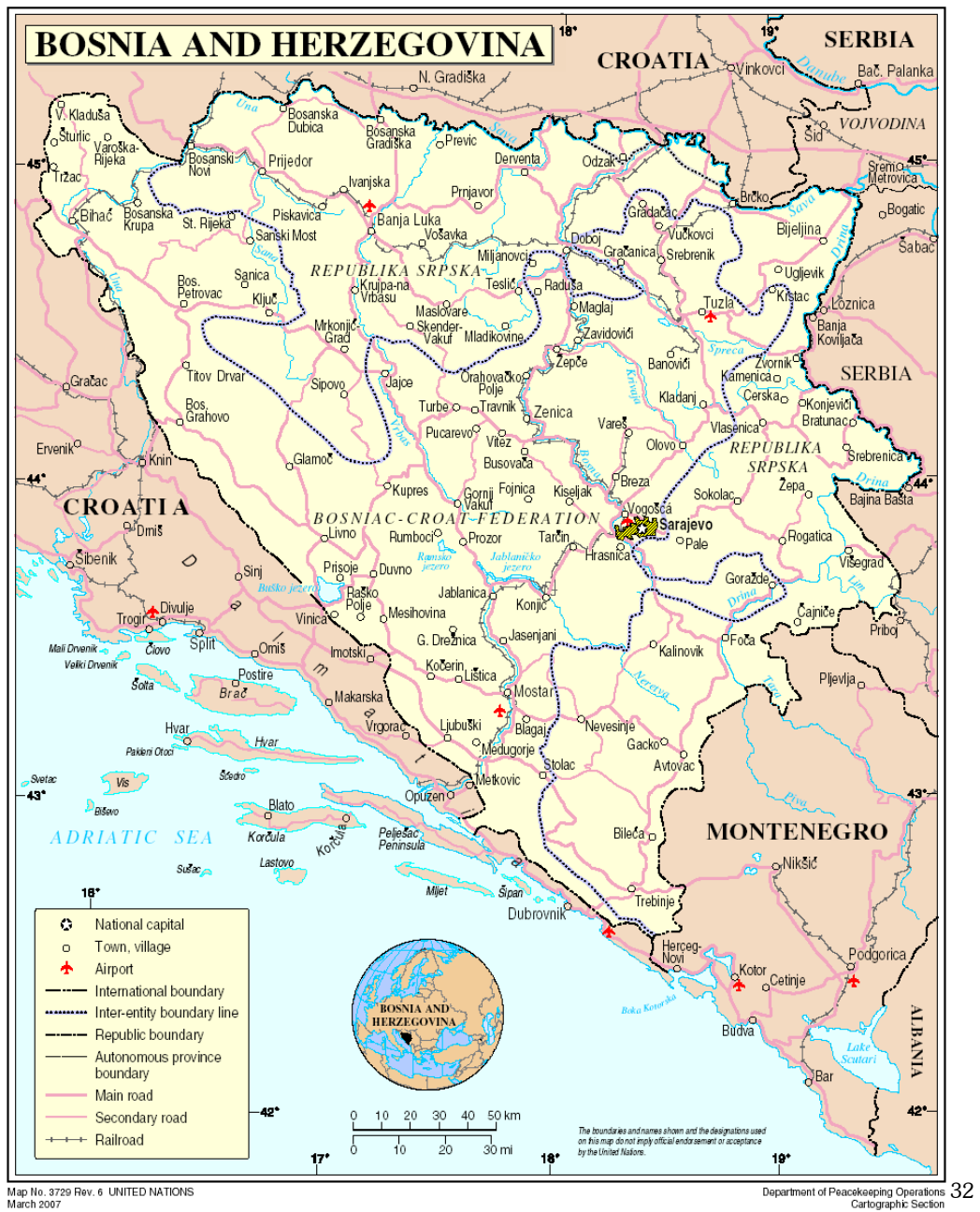

${ }^{32}$ Mapa disponível em:

$<$ http://www.un.org/Depts/Cartographic/map/profile/bosnia.pdf > . Acesso em: 31/jul./2011. 
Campos de estupro

\section{Estupro}

Brownmiller, em Against our will (1993), inicia o capítulo sobre estupro em guerras apontando a obviedade dessa prática nesses contextos. O estupro aparece, assim, como um produto inevitável da guerra - remetendo a uma citação do General George S. Patton Jr.: "inquestionavelmente" (é a expressão do general) "devem haver alguns estupros" (1993:31). ${ }^{33}$

Segundo Hayden (2000), entretanto, o estupro não é um simples produto da guerra, dado que não ocorre em todo conflito, mas sim quando a transferência de população se faz necessária. $\mathrm{O}$ estupro entra aqui, portanto, não como mais um item na seqüencia de excessos possíveis numa guerra, como Brownmiller chama a atenção, mas como o ato por excelência de limpeza étnica.

Posto isso, procuro nesta parte mapear o debate acerca do estupro na guerra, tendo em vista o que foi dito sobre a guerra até aqui $e$, especialmente, os pontos elencados (e aqueles que deveriam ter sido) no mote que introduziu esta reflexão.

Em primeiro lugar, um ponto importante que o debate feminista acerca do estupro (apesar dos embates) trata refere-se à sociedade patriarcal, enquanto aquela que faz com que a violação de mulheres seja uma possibilidade. Nela, os homens são simples falos, ou detentores de poder; de um modo ou de outro, subjugam as mulheres, e estas se submetem.

Para Brownmiller (1993), na sociedade patriarcal, a possessão da mulher é o símbolo do sucesso masculino, e sua defesa motivo de orgulho para o homem. O estupro na guerra, portanto, seria uma mensagem entre os homens, em que o lado derrotado perde todas as ilusões de poder e propriedade. ${ }^{34}$

As críticas a esse ponto de vista, também no debate feminista, buscam resgatar a agência das mulheres, questionando

\footnotetext{
33 No original: "unquestionably there shall be some raping".

34 Sobre isso, ver também Veena Das (1995, 2007).
} 
seu papel meramente passivo nessa sociedade. E apontam para o perigo de conceitualizar o estupro como mera comunicação entre os homens e as mulheres como corpos a serviço das economias de honra e poder que operam na guerra.

A imagem da vítima de estupro oscila assim entre esse instrumento simbólico de comunicação entre homens e, no intuito de retomar sua agência, a da mulher que dá o corpo, mas não dá a vida por exemplo, como aparece no relato de Hasiba, moradora de Višegrad: "Você deve ter sangue frio (...). Você está nas mãos deles e quer apenas sobreviver; você faz então qualquer coisa para se manter viva" (Stiglmayer, 1994:126). ${ }^{35}$

Mesmo o silêncio ou o segredo que muitas mulheres vítimas de estupro guardam consigo podem ser pensados como um modo de agência, ou um cálculo de minimização dos danos e do sofrimento, informado pelo meio que as circunda. ${ }^{36}$ Reviver a história e fazer com que outros a revivam talvez torne esse segredo um fardo menor a ser carregado.

Um segundo ponto que o mote não atenta é o fato de que homens e crianças também foram estuprados ou sofreram violência sexual.

Concordando com Cahill (2001), no caso da guerra na Bósnia, essa ênfase, de fato, minimiza o dado de serem as mulheres as principais vítimas de estupro, embora "aumente" as atrocidades dos perpetradores, como se o estupro de homens $e$ crianças fossem "piores" do que os estupros de mulheres.

Há uma hierarquia de plausibilidades. A violência sexual contra a mulher é vista como algo mais normal, mais dizível, mais compreensível, do que a violência sexual contra homens, crianças $e$ idosas. No caso da guerra na Bósnia, o estupro de mulheres também foi hierarquizado. No mote deste artigo, privilegiei os

35 "You have to be cold-blooded (...) You're in their hands, and you just want to survive; you'd go along with anything, if you only want to stay alive".

${ }^{36}$ Não há agência pura, desprovida de disposições e constrangimentos, como diria Bourdieu (1980), habitus e agência estão interligados. 
"piores", caracterizados como os estupros em série, em campos ou com intuito de engravidar a mulher. A violência episódica contra mulheres que teriam sido estupradas "somente" uma vez seria uma violência "menor", por assim dizer. Banjeglav (2009) enfatiza o perigo dessa hierarquização, dado que invisibiliza as consideradas formas "menores" ou "menos atrozes" de estupro na guerra.

Interessante notar que essa hierarquia de horrores não se dá somente em relação ao estupro, mas aparece na resignação de pessoas em Sarajevo ao contar que "só" perderam a mãe durante a guerra, ou "somente" o pai, a avó e um primo foram mortos. Essas falas vinham acompanhadas de uma frase que muitos compartilham: "tem gente que perdeu a família inteira". As formas "piores" de estupros são também as privilegiadas nas narrativas locais.

Paralelamente, a violência sexual e reprodutiva, em grande quantidade e sistemática, aparece como modo de justificar o estupro como arma de guerra e, no caso da Bósnia, de extermínio/genocídio e limpeza étnica.

Não penso "genocídio" e "limpeza étnica" como sinônimos. Embora a definição do que aconteceu em determinadas partes da Bósnia seja um debate, tomo como genocídio e extermínio o que aconteceu em Srebrenica, por exemplo (poderíamos talvez argumentar que não foi bem um genocídio, mas um androcídio, dado que somente os homens foram mortos). "Limpeza étnica" supõe transferência de população, que pode ocorrer de modo induzido - quando se promulga leis que ignoram a presença de minorias no território ou nas quais estas têm poucos direitos, ou têm os mesmos direitos que o da maioria (que são na realidade os direitos da maioria impostos sobre elas) -; ou violento (não que a perda de direitos à saúde, trabalho e moradia não sejam também formas de violência), sob coação, ameaças, brutalidades, estupros, queima de propriedades etc. ${ }^{37}$

${ }^{37}$ Sobre isso, ver também Hayden (1996b). 
O estupro, a meu ver, foi sim uma arma de extermínio ou genocídio, mas do ponto de vista do perpetrador. Não acredito que do ponto de vista da vítima ele tenha funcionado dessa maneira, embora tenha contribuído para a limpeza étnica, fazendo com que a vítima não deseje mais retornar para sua vila ou cidade. É uma arma de extermínio, pois vê mulheres enquanto corpos e receptáculos de sêmen, objetos para serem usados para diversão e procriação. A profanação dos $\operatorname{corpos}^{38}$ tornaria impuras as mulheres, que seriam, assim, rejeitadas pelos seus. E os filhos ou filhas do estupro, dado a concepção patrilinear (ideal) de sociedade, seriam sérvios ou sérvias (ou outros, dependendo da ascendência nacional do estuprador). Não ouvi relatos de que as mulheres tenham sido rejeitadas por suas famílias, tampouco há notícias de crianças que tenham virado "sérvias" tendo sido criadas em outro meio.

Não obstante, a motivação sexual do estupro aqui é evidente (Cahill, 2001), somada ao fato de que meninas $e$ mulheres, as mais bonitas e em idade reprodutiva, no geral, eram as escolhidas (Cf. Stiglmayer, 1994).

O terceiro ponto a sublinhar é que não foram somente as bosniaquinhas estupradas; sérvias, croatas e "indeterminadas" também foram (Bassiouni; McCormick, 1996 apud Kesić, 2002:321). Segundo os dados recolhidos pela equipe de Bassiouni (1994),

\begin{abstract}
Foram apontados todos os "lados em guerra" como perpetradores de estupro e violação sexual. Além disso, muitos grupos étnicos foram apontados como vítimas de estupro e violência sexual: muçulmanos bósnios, sérvios bósnios, croatas bósnios, croatas, sérvios da Croácia, muçulmanos da Croácia, albaneses, tchecos e outros. ${ }^{39}$
\end{abstract}

\footnotetext{
${ }^{38}$ Corpos despojados da pessoa, poluídos, pois violados, desnudados de sua humanidade. Sobre essa noção, ver Nahoum-Grappe (2002).

39 "Rape and sexual assault have been reported to have been committed by all of the "warring factions". Additionally, many ethnic groups were reportedly victims
} 
Stiglmayer (1994) também reporta casos de estupros de sérvias ocorridos em Sarajevo e Zenica e em campos croatas no norte da Bósnia. Talvez se eu tivesse vivido ou realizado pesquisa de campo na Republika Srpska ou em áreas de maioria croata da Federação, teria tido maior acesso a estes relatos. Sobre estes, de fato, não se fala muito. Provavelmente, como vimos, não ocorriam tão sistematicamente e, exceto este campo citado por Stiglmayer (idem), eu não soube de outros onde as mulheres eram mantidas aprisionadas com esse propósito. Nota-se aqui, portanto, tanto a hierarquização dos estupros entre os "sistemáticos" e os "isolados", quanto a sua etnização, já que, citando novamente Bassiouni (1994):

(...) é importante evitar uma equivalência moral na análise. A grande maioria das vítimas é muçulmana bósnia e a grande maioria dos perpetradores é de sérvios bósnios. Acredita-se que os sérvios foram responsáveis por mais de $60 \%$ dos aproximadamente 150 locais de detenção onde homens $e$ mulheres foram estuprados $e$ violados sexualmente. Por fim, com o propósito de denúncia, é importante distinguir entre crimes "oportunistas" e o uso do estupro e da violação sexual como método de "limpeza étnica". 40

Tendo em vista a teoria de Hayden (2000) sobre territórios heterogêneos que devem ser transformados em territórios homogêneos para possibilitar sua partição, pode-se notar que o

of rape and sexual assault: Bosnian Muslims, Bosnian Serbs, Bosnian Croats, Croatians, Croatian Serbs, Croatian Muslims, Albanians, Czechs and others."

40 "(...) it is important to avoid moral equivalency in the analysis. The vast majority of victims are Bosnian Muslim and the great majority of alleged perpetrators are Bosnian Serb. Serbs reportedly run over 60 percent of the nearly 150 detention sites where men and women were allegedly raped and sexually assaulted. Finally, for purposes of prosecution, it is important to distinguish between 'opportunistic' crimes and the use of rape and sexual assault as a method of 'ethnic cleansing'." 
boom dos relatos sobre os estupros deu-se entre 1992 e 1993, quando as forças sérvias predominantemente reorganizaram etnicamente o território. A guerra entre forças muçulmanas e croatas na Bósnia central entre 1993 e 1994 foi também uma guerra de limpeza étnica. Cidades como Travnik, por exemplo, passaram a ser principalmente muçulmanas, e outras como Vitez, principalmente croatas. Ambas as cidades possuíam população quase equivalente de croatas e muçulmanos. No entanto, não tenho informações se ocorreram estupros nesse momento, apesar de terem ocorridos "casos isolados" entre 1992 e 1993 nessa região (Cf. Bassiouni, idem).

$\mathrm{O}$ quarto ponto não questionado no mote remete ao número de vítimas de estupro. A Comissão da Comunidade Europeia aponta para 20.000 casos (id. ib.), mas outras fontes apontam para estatísticas bem maiores (entre 60 e 100 mil). Essa oscilação ocorre porque, além da inexistência de autópsias, o estupro é algo sobre o que, por mais que se fale, muito se silencia. Não obstante, esse número pode ser menor, pois houve e ainda há muita propaganda política em torno disso, que aponta para atrocidades maiores e menores de um ou de outro grupo.

Arnaut (s.d.:8) explica que esses números da comissão de pesquisa da Comunidade Europeia contabilizam as estupradas até dezembro de 1992. O centro médico de tratamento de vítimas de estupro e violência sexual "Medica Zenica", segundo a autora, tratou em torno de 28 mil mulheres de 1993 a 1997. A associação "Mulheres - vítimas da guerra", de Sarajevo, possui dados de 25 mil pessoas estupradas ou vítimas de violência sexual. Sobre os filhos nascidos do estupro não há números aproximados.

Os números que Stiglmayer (1994) cita são similares: 20 mil, incluindo bosniaquinhas, sérvias, croatas e "indeterminadas", de acordo com a Comissão da Comunidade Europeia, e 50 mil de acordo com o Ministério do Interior bósnio (MUPBiH).

A questão da propaganda de guerra, por sua vez, aponta como o estupro foi de fato utilizado com objetivos políticos para alimentar o medo e a oposição inter-nacional (ou interétnica) - via 
veículos de imprensa locais, especialmente. Um momento marcante, nesse sentido, foi o utilizado pela propaganda nacionalista sérvia antes mesmo das guerras, como uma das justificativas para a anulação da autonomia de Kosovo (província da Sérvia) em 1989: o estupro de uma sérvia por um albanês foi amplamente divulgado na mídia: "eles estão estuprando nossas mães e irmãs". Essa forma de noticiar o estupro foi muito utilizada durante as guerras na ex-Iugoslávia, por todos os lados.

$\mathrm{O}$ estupro foi em si um instrumento de propagação do medo, mas seu uso - em números, notícias etc. - fez com que a mensagem "entre homens" fosse passada: a mulher enquanto um corpo étnico, símbolo da família, mãe da nação, quando violentado, encerrava a vitimização de toda a nação e a necessidade de proteção por seus homens (ou apontava para seu fracasso, espécie de castração simbólica dos seus defensores ${ }^{41}$ ).

$\mathrm{O}$ quinto ponto, já abordado indiretamente, aponta para o problema da coletivização das vítimas e dos culpados, ou sua etnização. As críticas em relação a esse ponto remetem ao fato de que a etnização ou coletivização da violência leva ao desaparecimento da mulher, que passa a ser vista apenas como um número e uma vítima membro de um determinado grupo. Sua subjetividade, sua intimidade, sua vida, sua voz são assim minimizadas ou eclipsadas ante a voz comum ou da comunidade.

Primeiramente, discordo da oposição entre vitimização $e$ agência (por mais que a vítima possa ser vista como momentaneamente "eclipsada" no ato do estupro ${ }^{42}$ ), pois é a

\footnotetext{
${ }^{41}$ Cf. Banjeglav, 2009.

${ }^{42}$ Cahill, em sua análise do estupro enquanto uma experiência do corpo (embodied experience), aponta que no momento do estupro as ações do estuprador "eclipsam" a agência da vítima de um modo sexual: "Por tornar impossível nesse momento a agência intersubjetiva da vítima, o estupro é uma violação sexual, corpórea, da condição básica de ser da mulher" (tradução de: "Because it renders impossible for that moment the victim's intersubjective agency, rape is a bodily, sexual assault on a woman's underlying conditions of being") (2001:132).
} 
partir da consciência de que foi cometido um crime contra si própria - aqueles que são acometidos de um crime recebem o nome de vítimas - que a agência contra esse crime se põe em ação.

No entanto, a crítica à coletivização está vinculada a um discurso no qual a mulher, enquanto vítima, reifica a ideia da masculinidade da nação e reifica seu lugar na sociedade patriarcal.

Segundo Banjeglav (2009), a coletivização do estupro objetifica a mulher enquanto "étnica", ou uma "vítima bosniaquinha" genérica, negando sua subjetividade, além de (novamente) tornar outras formas de estupro invisíveis. Nas palavras de Kesić (1999:195 apud Banjeglav, 2009:40),

a polarização de grupos de mulheres em torno do estupro $e$ de suas vítimas corrobora para a ideologia dos nacionalistas de criar dentro da nação a ideia de homogeneidade, que iguala autoidentidade e nação e busca manipular as mulheres enquanto símbolo da luta nacional. ${ }^{43}$

O estupro visto dessa maneira contradiria também a realidade multicultural da Bósnia pré-guerra.

O estupro enquanto arma de guerra foi, contudo, eficaz: infringiu o medo, facilitando a limpeza étnica, consumou a partilha $e$ objetificou suas vítimas, definindo-as de acordo com sua etnia/nacionalidade. Parece, entretanto, que por uma manobra retórica, ou mesmo pelo silenciamento em relação à derrota da vida comum pelo nacionalismo, essa vida comum nascerá novamente. Nesse sentido, a propaganda nacionalista e o discurso feminista antinacionalista se aproximam: ambos, com suas ideologias e desejos, tentam moldar o real à luz de suas teorias; infelizmente parece que a primeira conseguiu fazê-lo.

\footnotetext{
43 “ $(\ldots)$ the polarization of women's groups over rape and its victims plays into the nationalists' ideology of creating homogeneity thought within the nation which equates self-identity with the nation and seeks to manipulate women as symbols of the nation's struggle."
} 
Por fim, retomando a questão da agência, talvez a coletivização da violência (ou sua representação enquanto algo coletivo) torne o fardo do estupro algo mais compartilhável, e o discurso étnico, um discurso incorporado, que lhes daria algum entendimento sobre o que aconteceu, para então seguirem suas vidas. E mais, se Brownmiller (1993), em sua análise sobre o estupro, tem um objetivo muito claro, que é o de evitar que a vítima seja culpabilizada pelo ataque que sofreu, a coletivização da violência e a brutalidade dos fatos no caso da Bósnia impedem que isso aconteça.

O sexto ponto que meu mote não questiona diz respeito ao problema de colocar o estupro num rol de horrores.

Durante meu trabalho de campo, diante de tantos horrores, esse era mais um. Como sublinhei anteriormente, o silêncio a respeito da violação dos corpos durante a guerra marcou minha pesquisa de campo. Conversas sobre o antes e o depois da guerra apareciam facilmente, mas o durante era apresentado como itens em sequência e separados por vírgulas - "foi uma guerra que contou com campos de detenção e de concentração, torturas, assassinatos, massacres, genocídios, estupros..." - ou aparecia em frases como "você sabe, tem nos livros, passou na televisão, não há muito que falar".

Hayden (2000:35), nesse sentido, relata a indignação de uma mulher "muçulmana bósnia" na plateia de uma conferência em Nova York sobre o genocídio na Bósnia, em 1993:

Quando se levantou o tópico sobre os estupros, uma mulher muçulmana bósnia da plateia, que caso contrário teria se mantido em silêncio durante a conferência, disse que, enquanto mulher bósnia, sentia que era inadequada a ênfase internacional ao estupro, pois todas as mulheres bósnias eram vítimas: elas perderam suas casas, seus filhos, seus maridos, seus empregos, suas vidas, e se haviam ou 
não sido violadas sexualmente não era o problema mais importante. Sua intervenção foi recebida com silêncio. ${ }^{44}$

Tal atitude, entretanto, leva-nos a deixar de atentar para a especificidade com que se deve lidar com o ato em si da violência sexual. Kesić (2002) lembra que todas as mulheres sentem medo e vergonha do que lhes aconteceu, sejam estupros ocorridos em uma viagem à praia, sejam no contexto da guerra. $\mathrm{O}$ estupro não é um horror como os demais, como tentei demonstrar, sua plausibilidade deve ser questionada.

Um sétimo ponto que chama também a atenção é a falta de informação sobre as crianças nascidas da violência sexual reprodutiva. São um fantasma. Os relatos apontam para o enorme número de abortos - a grande maioria realizava abortos assim que se descobria grávida - $e$ as que tiveram as crianças, as entregavam para a adoção. $\mathrm{O}$ único relato que me deparei de uma mãe que não entregou a criança para a adoção é fictício e está ilustrado no filme Grbavica (ou Em Segredo). ${ }^{45}$

Grbavica conta a história de uma mulher e sua filha adolescente que acredita ser filha de um šehid (ou chahīd, mártir islâmico), denominação que receberam os soldados bosniacs que morreram na guerra. A história do filme gira em torno de uma excursão da escola, que custa uma fortuna, mas é de graça para filhos de šehidi (pl.), e da mãe, que trabalha dia e noite para poder pagar pela viagem da filha (mesmo ela sendo, supostamente, filha de šehid). A filha, desconfiada, começa a pressionar a mãe para que lhe conte a verdade sobre seu pai. A mãe finalmente

\footnotetext{
44 "When the topic of rapes was raised, a Bosnian Muslim woman participant, who had otherwise been silent at the conference, said that as a Bosnian woman, she felt that the international emphasis on rape was inappropriate, because all Bosnian women were victims: they lost their homes, their sons, their husbands, their jobs, their lives, and whether they had been sexually assaulted or not was not really the most important problem. Her interjection was met with silence."

${ }^{45}$ Cf. Grbavica. Bósnia-Herzegóvina, Áustria, Croácia e Alemanha, 2006. Direção de Jasmila Žbanić. 90 min. [título em português: "Em Segredo"].
} 
desvenda que ficou em um campo de estupro em Grbavica, bairro de Sarajevo sob domínio das forças sérvias durante a guerra, onde foi estuprada por vários homens e inúmeras vezes.

O filme é justamente uma denúncia do silêncio em relação às mulheres vítimas de estupro durante a guerra, exemplos vivos da derrota da nação. Os combatentes mortos, em contrapartida, foram transformados em heróis e mártires e são tidos como símbolos da comunidade e do orgulho nacional.

Para finalizar, meu mote não questiona o fato de priorizar a visão "genocidal" (termo recorrente na literatura) do estupro no caso da Bósnia.

Qual o problema dessa visão? Em primeiro lugar, ela serve aos interesses nacionalistas. Em segundo, fazendo das palavras de Hayden (2000:34) as minhas:

ao mesmo tempo em que as denúncias por estupro genocidal podem ser justificadas para fazer justiça às vítimas individuais, elas servem para reforçar e reproduzir a mensagem da oposição étnico-nacional coletiva, que produziu primeiramente os estupros, tornando, assim, a reconciliação improvável. A exibição das vítimas, enquanto prova da necessidade de serem protegidas pelos seus conacionais, tem sido o principal instrumento na promoção dos nacionalismos na Europa pós-comunista (...) $e$ especialmente na ex-lugoslávia. ${ }^{46}$

Todavia, este parece ser um problema retórico, novamente, embora durante a guerra tenha sido um problema prático (bélico e

\footnotetext{
46 “(...) while prosecuting for genocidal rape may well be justified for reasons of justice for individual victims, it may serve to reinforce and reproduce the message of collective ethno-national opposition that produced the rapes in the first place, thus making reconciliation unlikely. The showy display of victims as proof of the need for protection of their conationals has been a major tool in the promotion of nationalisms in postcommunist Europe (...) and especially in the former Yugoslavia."
} 
político, se quisermos), de se marcar, definir, construir esse outro etnicamente.

De acordo com o Direito Internacional Humanitário, o estupro em massa ocorrido durante a guerra foi, por fim, considerado crime de guerra ${ }^{47}$ ("os perpetradores estão ligados a um lado do conflito e agem contra cidadãos neutros ou cidadãos do Estado beligerante"), crime contra a humanidade ("há evidência do envolvimento do Estado, pelo menos em termos de tolerância, nos fatos reportados, que conformam o ataque sistemático contra a população civil e têm pretextos nacionais, políticos, étnicos ou religiosos" ${ }^{48}$ ), violação das leis e costumes de guerra ("proibem expressamente o estupro e outras violações sexuais"), e genocídio ("os atos foram cometidos com o intuito de destruir totalmente ou em parte um grupo nacional, étnico, racial ou religioso").

Se essas leis partem do princípio de que há diferentes grupos em questão e de que há civis e combatentes numa guerra, é evidente que há uma essencialização desses grupos. Porém, essa é uma consequência da guerra, e deve ser encarada como um fato, um elemento do real, e não como um impedimento ético $e$ moral a uma análise do que aconteceu que incorpore também esses parâmetros.

${ }^{47}$ Definições extraídas de Cleiren (1994). No original: "the perpetrators are linked to one side of the conflict, acting against neutral citizens or citizens of a belligerent State"; "there is evidence of State involvement, at least in terms of tolerance, that the alleged facts form a part of a widespread or systematic attack against any civilian population, and that the crimes are based on national, political, ethnic or religious grounds"; "expressly prohibits rape and other sexual assaults"; "the acts were committed with the intent to destroy, in whole or in part, a national, ethnic, racial or religious group".

${ }^{48}$ A definição de Hannah Arendt em relação a este crime é bem mais interessante. Segundo ela, o extermínio dos judeus europeus constituía um crime contra a humanidade "na medida em que (...) atentava contra a pluralidade, traço inerente à condição humana, sem o qual a espécie humana era inconcebível" (Stolcke, 2002:104). 
Não obstante, o grande medo desses autores diz respeito também ao perigo da coletivização étnica da culpa, como ocorre em relação às vítimas. Os relatos apontam que isso não é uma regra. Em Sarajevo, chamam-lhes de "agressores" ou "chetniks". Mulheres estupradas chamavam seus estupradores também de chetniks ou silenciavam sobre "quem seriam eles" (lembrando de suas insígnias e uniformes). ${ }^{49}$ Chamavam a atenção de que alguns lhes ajudaram e que muitos eram forçados a estuprá-las. ${ }^{50}$ Chamavam-lhes pelos nomes, pois muitas vezes os conheciam. Sabiam quais eram piores, mais violentos. E chegaram a procurar ajuda da polícia em busca de filhas desaparecidas, acreditando ainda na autoridade e na justiça, mesmo ela sendo "sérvia" (Cf. Stiglmeyer, 1994, vários depoimentos).

O mote

qualquer experiência individual
de estupro está profundamente
ancorada no meio social e
político circundante, que é
também afetado pelos modos
como a vítima, o agressor, suas
famílias, e várias instituições
reagem e representam o
acontecido
$\left(\right.$ Cahill, 2001:127) ${ }^{51}$

${ }^{49}$ Cf. Stiglmayer, 1994.

${ }^{50}$ Kadira, que foi estuprada no campo de Doboj, conta que os piores eram os que vinham de fora e que conhecia vários de seus estupradores, que alguns deles se divertiam, outros eram forçados a fazê-lo, e que três conhecidos seus, que se recusaram, foram mortos (Cf. Stiglmayer, 1994:120).

51 “(...) any individual experience of rape is deeply embedded in the surrounding social and political environment, which is itself affected by the ways the victim, the assailant, their families, and various institutions react to and represent the incident". 
Como afirmei na introdução, no mote deste artigo transparecem as narrativas que ouvi em campo, ou seja, a fala dos que sofreram a agressão. Neste momento conclusivo do artigo, volto a dois exemplos em que transparece claramente a que tipo de narrativa me refiro.

A associação "Mulheres - Vítimas da Guerra", presidida por Bakira Hasečić, também vítima de estupro, assim descreve os acontecimentos da guerra $^{52}$ :

Durante a agressão ao país Bósnia-Herzegóvina de 92 a 95, entre os seus mais ameaçados habitantes estavam as mulheres, que vivenciaram enormes danos materiais $e$ psicológicos. Acometeram-nos crimes de violência sexual, abusos físicos indizíveis para um ser humano normal.

Fomos mortas, jogadas em buracos e valas comuns. Fomos estupradas em massa, raptadas, trancadas em prisões $e$ campos, torturadas (...), levadas a fazer trabalhos forçados, expulsas à força de nossas vilas e cidades, pilharam nossos imóveis e bens de valor e inúmeras outras formas brutais de humilhação, e não raramente, meninas entre 12 e 14 anos eram retiradas à força de suas famílias e levadas a locais específicos, onde eram submetidas a terríveis torturas, estupradas e submetidas a outras formas de abusos, incluindo punições físicas e morte.

Agradando ou não, nós precisamos dizer que mulheres bosniaquinhas foram estupradas em massa $e$ sistematicamente. Tal crime é a ideologia daqueles cujo objetivo era realizar a pior forma de genocídio - estupro.

Em suma, a limpeza étnica dos habitantes bosniacs (...) desenrolou-se de acordo com um cenário planejado de antemão. Em segundo lugar, aqueles que planejaram a agressão à $\mathrm{BiH}^{53}$ sabiam bem que a partir de estupros brutais em massa e do abuso das bosniaquinhas atingiriam

\footnotetext{
${ }^{52}$ Ver original na parte "sobre nós" (O nama) da página na internet dessa associação (Cf. www.zena-zrtva-rata.com).

${ }^{53}$ Bósnia-Herzegóvina, ou Bosna i Hercegovina. A forma abreviada é do original.
} 
o cume da pirâmide étnica da nação bosniac, e deste modo, com o objetivo da limpeza étnica, impeliriam as pessoas ao êxodo, especialmente daqueles lugares onde formavam a maioria da população, como foi o caso no leste da Bósnia. É difícil dizer aqui o número exato de mulheres estupradas e vítimas de abuso durante a agressão à $\mathrm{BiH}$. Não é pequeno o número de mulheres estupradas que preferiram o silêncio, tamanha é a dor, e não desejam dividir sua terrível humilhação com ninguém.

Muitas foram levadas para a Sérvia e Montenegro onde foram abusadas e estupradas, tiveram filhos que então deixaram. Algumas ficaram com as crianças, algumas as deram para a adoção, centenas de mulheres interromperam a gravidez (não desejando dar a luz a uma criança fruto de um estupro). Muitas meninas e moças não desejam nunca casar. Muitas, devido ao estupro, foram largadas pelos maridos, e sobre muitas nem os maridos, nem os membros da família sabem o que lhes aconteceu.

Os estrategistas e planejadores da agressão conheciam muito bem as vítimas. Sabiam tudo sobre seus valores morais e culturais, sua adscrição religiosa, o ambiente psicossocial em que viviam. Sabiam precisamente qual a reação que o estupro provocaria na vítima e no seu meio imediato - família, parentes e vizinhos.

Os riscos são, claro, reais, mas passageiros. A verdade é eterna e deve vencer o medo que está na lembrança da vítima. Das muitas ameaças declaradas que sofreram, ecoa aquela que diz: "Se disser a alguém o que aconteceu com você, será morta". A ameaça mantém a vítima em constante medo de contar a verdade. A luta pela verdade vence em muitos casos, mas sabemos que seguramente há ainda muitas histórias não contadas...

Por isso, nós rompemos o silêncio, falamos claramente sobre os estupros $e$ abusos que aconteceram durante a agressão contra à BiH.”

Apesar do relato fortemente marcado pelo modo tido como "genocidal" de ver o que aconteceu, a associação "Mulheres - 
Vítimas da Guerra" busca "fazer justiça" às vítimas. Assume-se enquanto "associação multiétnica, multi-nacional e apartidária" e visa reunir depoimentos para que "não se esqueça o que aconteceu", além de trabalhar no intuito de reivindicar recursos sob a forma de pensão para essas mulheres, que precisam de cuidados médicos e psicológicos. A associação diz ainda colaborar com o TPI (Tribunal Penal Internacional para a ex-lugoslávia) $e$ com o Tribunal da Bósnia-Herzegóvina, também encarregado de julgar criminosos de guerra, no sentido de reunir informações $e$ provas contra esses criminosos; além de trabalhar para ajudar mulheres que não podem retornar às vilas e cidades de onde foram expulsas. ${ }^{54}$

Muitos dos itens elencados por essa associação condizem com um modo de reivindicação que encontra respaldo nas organizações internacionais e de ajuda humanitária.

Não vejo como as necessidades dessas mulheres seriam atendidas se sua vitimização não traduzisse a vitimização de uma coletividade, e se não dissessem respeito à "identidade da vítima de estupro" que, como afirma Banjeglav (2009), é geralmente muçulmana e de comunidades rurais, muitas vezes vistas como meninas castas e virgens, e não uma mulher emancipada $e$ moderna das cidades, como o eram muitas.

Todavia, aqui parece ecoar a afirmação de Hannah Arendt: se me atacam como judeu, defendo-me como judeu (Cf. Stolcke, 2002:96). E é assim que essas mulheres fazem, defendem-se como mulheres e como bosniaquinhas. Se sua subjetividade é violada, se cada caso é um caso, certamente, se seu violador for preso $e$ ela tiver os recursos necessários para receber o atendimento médico e psicológico ou a ajuda financeira que precisa, poderá trabalhar assim sua subjetividade. A prisão do violador aqui é

\footnotetext{
${ }^{54}$ Tais informações foram também tiradas da página da internet dessa associação. Um dos itens do Acordo de Dayton é o retorno dos refugiados. De algum modo, todas as associações de vítimas da guerra devem abordar esse tópico.
} 
mais que um problema abstrato de se fazer justiça, diz respeito ao fato muito concreto dessa mulher não ter mais que cruzar com ele em sua vila/cidade natal toda vez que for comprar pão - e esse é um dos grandes impedimentos ao aclamado "retorno dos refugiados". 55

Vesna Kesić, feminista da Croácia, criticou severamente, durante a guerra, a forma "genocidal" de se entender o estupro e a construção patriarcal de gênero nela subentendida, em que o papel primordial das mulheres é a reprodução biológica da família e da nação (Cf. 2002:316). Ela se explica:

O que está sendo aqui discutido, abandonado $e$ instrumentalizado para propósitos nacionalistas, políticos, militares ou, algumas vezes, "apenas profissionais" (jornalísticos) são corpos de mulheres que sofrem [women's bodies in pain $].^{56}$ Porque os estupros de guerra $e$ outras formas de violência contra as mulheres estavam tão

\footnotetext{
${ }^{55}$ Senad, um amigo jornalista, que ficou seis meses preso durante a guerra em um campo de concentração em Pale, cidade ao lado de Sarajevo, onde era torturado e espancado diariamente, foi contatado pelo jornal $O$ Estado de $S$. Paulo para falar sobre a prisão de Karadžić, em 2008: "Não me interprete mal", disse ele, "É uma boa notícia. A comunidade internacional precisava de algo assim e nós, bósnios, sabemos que [ele] personifica todo o mal que nos aconteceu. (...) Tenho certeza de que as mães de Srebrenica estão felizes. Meu vizinho também está feliz. Mas amanhã nos levantaremos e a dor continuará a mesma. E enquanto o culpado anônimo, o que deu os tiros, o que estuprou ou torturou, continuar livre, será impossível superar alguma coisa" (Pérez, 27 jul. 2008).

56 "What is here contested, dispensed with, and instrumentalized for nationalistic, political, military, or other, sometimes 'merely professional' (journalistic), purposes are women's bodies in pain. Because war rapes and other forms of violence against women were so tightly enmeshed within the categories of nation and ethnicity, they could be recognized as a war strategy, subjected to indictments as war crimes, and juridically sanctioned - in short, taken seriously - only if they occurred in large numbers (whatever 'large' means), if they were 'systematic' and 'followed a pattern', and if they supported the claim of genocide or ethnic cleansing. Even then, if perpetrators were brought to court, it was left to women to prove, argue, and corroborate their crimes".
} 
fortemente imbricados às categorias de nação e etnicidade, eles puderam ser reconhecidos como estratégia de guerra, indiciados como crimes de guerra, e juridicamente ratificados - ou seja, levados a sério - somente quando ocorressem em grande número (seja lá o que signifique "grande"), fossem "sistemáticos" e "seguissem um padrão", e caso corroborassem para a ideia de genocídio e limpeza étnica. Mesmo assim, ainda que os perpetradores fossem levados a julgamento, caberia às mulheres provarem, argumentarem e confirmarem seus crimes (2002:317).

Parece que essas mulheres da associação "Mulheres Vítimas da Guerra" sabem disso e escolhem fazer desta a sua voz.

Cito agora um artigo de Meldijana Arnaut (s.d.), jornalista e pesquisadora do "Institut za istraživanje zločina protiv čovječnosti i međunarodnog prava" (Centro de Pesquisa em Crimes contra a Humanidade e contra o Direito Internacional), de Sarajevo:

\begin{abstract}
A posição e o papel da mulher na guerra reflete sua posição e papel na sociedade, mas também na coletividade nacional. Por mais que a mulher seja um ator importante na arena nacional, não somente pelo seu papel biológico crucial, como também na reprodução cultural da nação, a maioria das teorias da nação e do(s) nacionalismo(s) ignora ou minimiza a relação de gênero (s.d.:7). ${ }^{57}$
\end{abstract}

Em seu artigo, Meldijana, para chamar a atenção para o caráter genocidal do estupro na Bósnia, pede que se observe a importância "cultural" e "biológica" da mulher para a nação e sociedade. O caminho que a autora faz é, nesse sentido, bem interessante. Ela desafia o patriarcalismo, fazendo os termos desse,

\footnotetext{
57 "Pozicija i uloga žene u ratu je odraz njene pozicije i uloge koju ima u društvu, ali i one koju ima $\mathrm{u}$ nacionalnom kolektivitetu. Iako su žene važni akteri nacionalne arene, ne samo zbog krucijalne uloge u biološkoj nego i u kulturnoj reprodukciji nacije, većina teorija nacija i nacionaliz(a)ma ignorira ili minorizira rodne odnose."
} 
seus próprios termos, para buscar, assim, o reconhecimento do lugar da mulher $n(e s s)$ a sociedade e na nação. Continuemos:

O papel da mulher é sempre relacionado ao papel da mãe $e$, em muitas culturas, é o símbolo do espírito da coletividade. As mulheres, na consciência coletiva, estão ligadas às crianças, às famílias às quais dão continuidade, $e$ à coletividade à qual pertencem (id.ib.:8)..$^{58}$

Os planejadores da agressão conheciam bem a mentalidade do habitante daqui. Seus objetivos eram ferir e humilhar a mulher enquanto membro de uma nação, de um povo (id.ib.:9). ${ }^{59}$

Numa sociedade como a bósnia - e mesmo a nossa - casar $e$ ter filhos são valores fundamentais. Podemos ler isso como sociedade patriarcal, ou como fez Meldijana, afirmando que as mulheres exercem papel fundamental na sociedade, na medida em que são a fonte biológica e cultural da nação. Essa nação, ou sociedade patriarcal, foi de fato ameaçada pelos estupros em massa: tanto pelo fato em si, como pelas consequências do estupro para a mulher. Entre mulheres "emancipadas $e$ modernas", para remeter ao termo de Banjeglav (2009), não vejo como as consequências do estupro seriam muito diferentes. De acordo com o texto da associação "Mulheres - Vítimas da Guerra", os estupros causaram nas mulheres consequências psíquicas, físicas e sociais. Segundo essa associação, são comuns problemas nervosos e cardiovasculares, diabetes, depressão, ansiedade, dificuldades sexuais, insônia, dificuldades de concentração e no trabalho. Muitas não querem casar e não conseguem ter relações sexuais. São mulheres que também

\footnotetext{
58 "Lik žene, najčešće oslikan u liku majke, u mnogim je kulturama simbol duha kolektiviteta. Žene se u kolektivnoj svijesti povezuju sa djecom, obitelji iz čega dalje proizilazi i kolektivitet kojemu pripada."

59 "Planeri agresije su dobro poznavali mentalitet ovdašnjeg življa. Cilj im je bio povrijediti i poniziti ženu, kao pripadnicu jedne nacije, jednoga naroda."
} 
perderam muitos parentes próximos e a própria casa. $\mathrm{O}$ que muitos chamam de stress pós-traumático é decorrente de todo um universo de perdas, incluindo o controle sobre o próprio corpo.

Ou seja, não devemos exigir que todas sejam cientistas sociais ou feministas, ou que todas desconstruam os biologicismos $e$ as ideologias patriarcais $e$ nacionais que as cercam.

Essas mulheres travam agora uma luta política. O Estado que as usou para a propaganda nacionalista as ignora, como ilustra o filme Grbavica e a reivindicação de Arnaut para que sejam vistas como fundamentais para a reprodução da sociedade. Posto isso, se queremos que elas recebam ajuda para moradia (a grande maioria é refugiada) ou tenham atendimento individualizado, e se o único modo de obterem recursos é como vítimas bosniacs, ou sérvias, ou croatas, ou albanesas de estupro ${ }^{60}$, e não como mulheres emancipadas simplesmente - embora sempre vítimas em potencial de estupro (já que este é um crime predominantemente cometido por homens contra mulheres, comprovando assim a distribuição injusta do medo e da insegurança nas sociedades ocidentais ${ }^{61}$ ) - deixemo-nas que o façam e que vistam esse papel. Quem sabe se unam novamente na luta por reparações e na dor que compartilham, ou mesmo na consciência de que foi uma guerra de homens e políticos, na qual elas perderam tudo e tiveram sua dignidade posta em cheque?

Compreender o estupro não desqualifica a forma de reivindicação do pós-guerra. Não são os homens e nem a nação que pedem às mulheres que se coloquem como uma bosniaquinha vítima de estupro. Elas encontram nesse papel também a possibilidade de algum consolo, no qual mesmo a ideia do estupro como arma de extermínio torna, como já afirmei, menos evidente a ignóbil conclusão acerca da obviedade $e$ normalidade do estupro em situações de guerra e na hierarquia sempre colocada pela diferença de gênero.

\footnotetext{
${ }^{60}$ Fazendo aqui uma referência tortuosa ao artigo de Kesić (2002).

${ }^{61}$ Cf. Burgess-Jacskon, 1994 apud Cahill, 2001:122.
} 
A etnização das vítimas, no entanto, é uma afronta para essas pessoas "emancipadas e modernas" e para as mulheres imersas na batalha contra os crimes sexuais e de gênero no mundo. No caso da Bósnia, entretanto, a etnização encontra uma eficácia, talvez mais prática do que simbólica. Serviu aos propósitos do acordo de paz e agora serve à luta política por melhores condições de vida daqueles que tiveram seu corpo marcado pela guerra.

Não se trata de defender a linguagem do nacionalismo, mas essas mulheres perceberam como podem agenciar a categoria de vítimas da guerra e do genocídio (o que de fato são também). E possivelmente assim também $\mathrm{o}$ fazem as mulheres sérvias $e$ croatas que foram estupradas. Quanto mais servirem de exemplo dos horrores perpetrados sobre si em nome de seu grupo nacional, mais possibilidades terão de que seus lamentos sejam ouvidos.

Sei que é uma bola de neve. A guerra transformou diferenças nacionais em divisões nacionais e étnicas. Trouxe a partilha do território. Cravou-a sobre os corpos e memórias das pessoas. Atualmente, a única língua que se entende é essa. A única que se ouve. A única que possui um espaço político. E corroboramos com isso sim ao fazermo-nos ouvir nessa língua comum. Talvez depois que tais mulheres receberem a ajuda que necessitam e seus violadores forem presos, poderemos discutir o estupro novamente em outros termos que não os termos colocados pela guerra.

Claro que, no fim, perdura uma tristeza. É só porque foram violentadas como bosniaquinhas (ou sérvias, croatas, albanesas...) que podem reivindicar direitos e justiça por terem sido violentadas. 
Conclusão

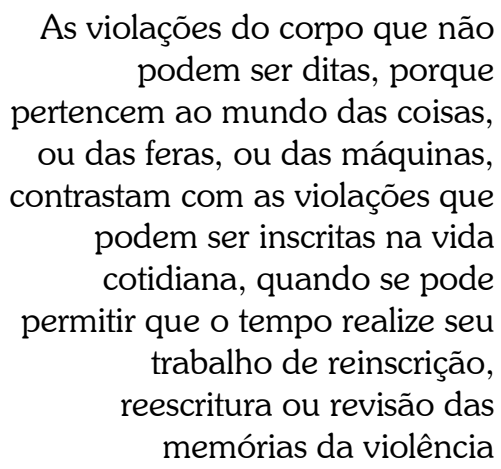

(Das, 1999:39).

Após tanto que foi dito, por que ainda podemos chamar tais estupros como do campo do indizível? - remetendo a Das (1999), que distingue as violências que podem ser ditas na vida cotidiana, daquelas que só podem ser contadas como grandes histórias da nação ou silenciadas no dia-a-dia.

Os relatos dos estupros nas narrativas que me deparei em campo vinham ou como um item na sequência dos horrores da guerra, ou como grandes textos que explicam ou formatam tais horrores na grande História da Guerra na Bósnia, ou seja, na história da agressão que sofreram e cujo objetivo era a partição do território.

Optei por essa história durante a pesquisa de campo (Peres, 2010), ao trabalhar mais com discursos do que com narrativas pessoais, ao escolher conversar trivialidades com meus novos amigos e conversar sobre a guerra com pessoas públicas, portavozes da fala, e não do silêncio, atores da vida pública e não personagens da vida cotidiana.

Contei aqui como essa história está sendo debatida e como a chamada questão nacional é um tema em disputa na Bósnia, que sempre se orgulhara de ser um país moderno, exemplo da pluralidade e da possibilidade da vida comum. 
O campo de batalha que se formou ao redor das significações do estupro na guerra na Bósnia retoma mais uma vez essa disputa, entre se pensar sob o ponto de vista que une - as vítimas - ou que as separa. Falar do estupro enquanto uma violação ao corpo étnico das mulheres parece reificar essa última ideia, o que não queremos. Não falar, é contar, entretanto, apenas uma parte dessa história.

\section{Referências bibliográficas}

ARNAUT, Meldijana. Silovanje: zločin koji se ćuti. Sarajevo, s.n., s.d.. Artigo cedido pela autora. [Estupro: o crime que se silencia].

BASSIOUNI, M. Cherif. (coord.) Annex IX. Rape and sexual assault. United Nations - Security Council. S/1994/674/Add.2 (Vol. V). 28 Dec. 1994. Final report of the United Nations Commission of Experts established pursuant to security council resolution 780 (1992). [http://www.ess.uwe.ac.uk/comexpert/ANX/IX.htm - Acesso em 30/jul./2011].

BAnJEGlaV, Tamara. Gender, Nation, Rape: Intersections of Gender and Ethnic Violence during the War in Bosnia and Herzegovina. Submitted to Nationalism Studies Program, Central European University, Budapest, Hungary, 2009. In partial fulfillment of the requirements for the degree of Masters of Arts.

Bougarel, Xavier; Helms, Elissa; DuIJZINGS, Ger. (eds.) Introduction. The new Bosnian mosaic: identities, memories and moral claims in a post-war society. Hampshire, Ashgate, 2007, pp.1-35.

BOURDIEU, Pierre. Les sens pratique. Paris, Les Éditions de Minuit, 1980.

BRINGA, Tone. Being Muslim the Bosnian way: identity and community in a Central Bosnian village. Princeton, Princeton University Press, 1995.

BROWNMILLER, Susan. Against our will: men, women and rape. New York, NY, Fawcett Columbine, 1993.

CAHILl, Ann J. Rethinking rape. Ithaka, NY, Cornell University, 2001.

Cleiren, Christine P.M. (coord.) Annex II. Rape and sexual assault: a legal study. Final report of the United Nations Commission of Experts 
established pursuant to security council resolution 780 (1992). S/1994/674/Add.2 (Vol. $\quad$ I). $28 \quad$ Dec. 1994. [http://www.ess.uwe.ac.uk/comexpert/ANX/II.htm - Acesso em: 30/jul./2011].

DAS, Veena. Life and words: violence and the descent into the ordinary. Berkeley, University of California, 2007.

. Fronteiras, violência e o trabalho do tempo: alguns temas wittgensteinianos. Revista Brasileira de Ciências Sociais, vol. 14, $\mathrm{n}^{\circ}$ 40, São Paulo, jun. 1999, pp.31-42.

- Critical events: an anthropological perspective on contemporary India. New Delhi, Oxford University Press, 1995.

HAYDEN, Robert M. Rape and Rape Avoidance in Ethno-National Conflicts: Sexual Violence in Liminalized States. American Anthropologist, New Series, vol. 102, n 1 , Mar. 2000, pp.27-41.

- Imagined Communities and Real Victims: SelfDetermination and Ethnic Cleansing in Yugoslavia. American Ethnologist, vol. 23, n 4, nov. 1996a, pp.783-801.

. Schindler's Fate: Genocide, Ethnic Cleansing, and Population Transfers. Slavic Review, vol. 55, n 4, Winter 1996b, pp.727-748.

KESIĆ, Vesna. Muslim women, Croatian women Serbian women, Albanian women. In: BJELIĆ, Dušan I.; SAVIĆ, Obrad. (eds.) Balkan as metaphor: between globalization and fragmentation. Cambridge, Mass., MIT Press, 2002, pp.311-321.

NACIONALNI sastav stanovništva: rezultati za republiku po opštinama i naseljenim mjestima 1991. Popis stanovništva, domaćinstava, stanova i polioprivrednih gazdinstava 1991. Sarajevo, Državni zavod za statistiku Republike Bosne i Hercegovine, dec./pros. 1993. (http://www.fzs.ba/Dem/Popis/nacionalni\%20sastav\%20stanovnistva \%20po\%20naseljenim\%20mjestima\%20bilten\%20234.pdf - Acesso em: 03/set./2011). [Composição nacional dos habitantes: resultado para a república por municipalidades e localidades 1991. Censo de habitantes, habitações (apartamentos e casas) e propriedades agrícolas 1991] 
Campos de estupro

NAHOUM-GRAPPE, Véronique. The anthropology of extreme violence: the crime of desecration. International Social Science Journal, Unesco, vol. 54, no 174, Dec. 2002, pp.549-557.

PERES, Andréa Carolina Schvartz. Contando histórias: fixers em Sarajevo. Tese de Doutorado em Antropologia Social. Universidade Estadual de Campinas, Campinas, 2010.

PÉREZ, Natália Rodríguez. "Quem me torturou não foi Karadzic". O Estado de S. Paulo, São Paulo, 27 jul. 2008, Internacional.

StiglmAYER, Alessandra. The rapes in Bosnia-Herzegovina. In: STIGLMAYER, Alessandra. (ed.) Mass rape: the war against women in Bosnia-Herzegovina. Lincoln and London, University of Nebraska, 1994, pp.82-169.

STOLCKE, Verena. Pluralizar o universal: guerra e paz na obra de Hannah Arendt. Mana, vol. 8, n 1, Rio de Janeiro, 2002, pp. 93-112.

ŽENA - ŽRTVA RATA. O nama. 2010. Disponível em: <www.zena-zrtvarata.com>. Acesso em: 30/jul./2011. [Mulheres - Vítimas da Guerra. Sobre nós.]

VulLIAMY, Ed. Seasons in hell: understanding Bosnia's war. New York, NY, St. Martin's Press, 1994. 